\title{
A comparison of several methods for estimating the nutritive value of proteins
}

\author{
BY W. P. RIPPON \\ Australasian Food Research Laboratories, Cooranbong, New South Wales, Australia \\ (Received 28 May 1958-Revised 30 December 1958)
}

Since Rubner (1879) first demonstrated a variation in the efficiency with which nitrogen from different proteins was retained in the body, many workers have investigated methods by which the 'biological value' of proteins might be determined and divers criteria to this end have been suggested. N-balance studies in growth, maintenance, reproduction, fertility and lactation, growth itself, and longevity, were all proposed for this purpose during the second decade of the present century. More recently carcass analysis, a chemical score based on the amino-acid content of the protein, the ratio of creatinine $N$ to total urinary $N$ and changes in liver $N$ have been related to protein quality.

A worker wishing to estimate the nutritive value of a protein food is confronted by this array of methods, each with its own particular advantages and handicaps. The purpose of this study was to examine six of the methods presently employed for the estimation of protein quality and to compare the convenience of the procedures that must be followed and the dependability of the results obtained by different criteria.

The following methods were studied: $\mathrm{N}$ balance (Thomas, 1909, I9 I ; Mitchell, 1923-4; Mitchell \& Carman, 1926; Mitchell, Hamilton \& Beadles, I945); protein efficiency ratio (P.E.R.) (Osborne \& Mendel, x917; Osborne, Mendel \& Ferry, I9r9); carcass analysis (Bender \& Miller, I953; Miller \& Bender, 1955; Dreyer, I957); changes in liver N (Kosterlitz, 1944; Henry, Kosterlitz \& Quenouille, 1953); chemical score (Mitchell \& Block, r946); creatinine: $\mathrm{N}$ balance in urine (Murlin, Szymanski \& Nasset, I948).

\section{EXPERIMENTAL}

\section{Animals}

Both albino and hooded rats were used in different tests, male rats only being selected, since Hoagland \& Snider (I926) claimed that males eat more and grow more quickly than females. Although Morgan (I93I) disagrees with their contention, I decided not to include any females.

At the beginning of each test, all animals available were assembled into groups of six to eight in such a way that the total weight of each group was about the same. Generally, weight was the only basis for grouping, but, in addition, some groups included equal numbers of animals from each litter represented. These groups are referred to as litter-mate groups. Each group of animals was allotted one of the foods being examined. No animal that failed to eat all the $\mathrm{N}$ supplement was considered in the final calculations. 


\section{Preparation of diet}

The protein-deficient diet used was based on wheat starch, and its components are given in Table $\mathrm{I}$.

Foods to be tested were analysed for $\mathrm{N}$ and the values found were used to determine the quantity to be given as supplement or the proportion in which it was to be mixed with the protein-deficient diet for feeding at the required content of protein. The following foods were tested: commercial casein, dried gluten flour, defatted heattreated soya-bean flour, defatted heat-treated groundnut flour, full-fat heat-treated soya-bean flour, full-fat heat-treated groundnut flour. The casein was supplied by the Camperdown Cheese and Butter Factory, Victoria, and the gluten flour by Brown and Dureau, Sydney. The soya flour was prepared from Queensland-grown beans of unknown variety which were heated by steam at $12 \mathrm{lb} / \mathrm{in}^{2}$ pressure for about $20 \mathrm{~min}$, then ground and dried at about $110^{\circ}$ to about $7 \%$ moisture. Roasted groundnut kernels were ground in a roller mill to a reasonably fine flour for use in these experiments. Defatted samples of both the soya-bean and groundnut flours were prepared by extracting the ground material with light petroleum (b.p. $40^{\circ}-60^{\circ}$ ) and drying the residue at $105^{\circ}$.

\section{Table I. Percentage composition of the protein-deficient diet}

$\begin{array}{lccr} & (\mathrm{N} \text { content } 0.09 \%) & \\ \text { Sucrose } & 7 & \text { Salt mixture* } & 4 \\ \text { Vitamin mixturet } & 5 & \text { Cod-liver oil } & \text { I } \\ \text { Butter } & 10 & \text { Wheat starch } & 73\end{array}$

The wheat starch was added after all the other ingredients had been thoroughly mixed together.

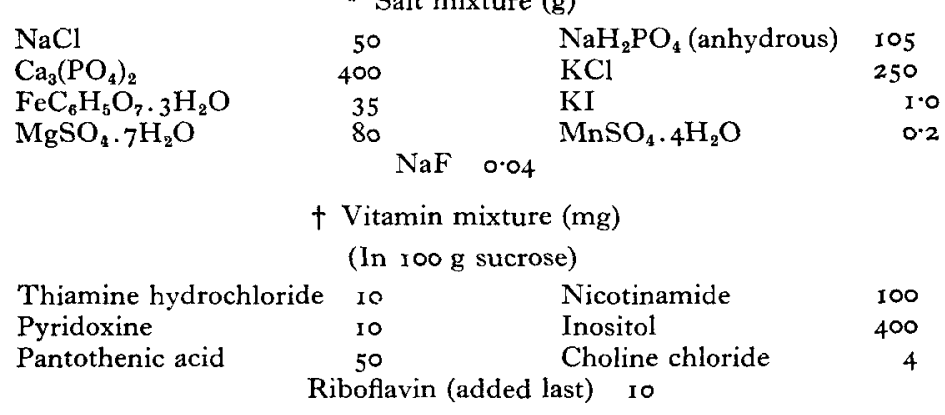

\section{Feeding}

At first, diets containing about 10 or $15 \%$ protein were prepared by mixing the test food with protein-free diet. 'Mixed diets', as these are called here, were given either ad lib. or in limited daily amounts, but later the food to be tested was given in weighed amounts separately from the protein-deficient diet which was offered without restriction. This method is referred to as 'pair feeding'. In ad lib. tests a weighed quantity of food was allotted to each animal and given without restriction. At the end of the test, the quantity remaining was weighed and the amount eaten calculated. Each morning all test animals in pair-feeding experiments were given the foods being 
tested in weighed supplements containing equal quantities of $\mathrm{N}$. When these were all consumed, the protein-deficient diet was offered ad lib. Next morning it was removed from the food tins, and supplements were offered again.

Cuthbertson, McCutcheon \& Munro (1940) studied the effect of giving carbohydrate separately from protein to both young and adult rats. They concluded that 'the metabolism of protein in the young rat remains unaffected', and that 'in the adult organism there is a loss of body $\mathrm{N}$ which although small and very close in amount to the minimum endogenous expenditure is almost always present'. Holemans \& Lambrechts (1955), however, obtained in one instance almost double the $\mathrm{N}$ retention on equal $\mathrm{N}$ intake when they increased the calories by about one-third, and it was thought better to avoid the possibility of giving insufficient calories and risk the small effect noted by Cuthbertson $e t$ al. which in any event was not always present.

\section{Length of test period}

Opinions on the time required for satisfactory results with the various methods lack unanimity. For example, Fixsen (1934-5), Mitchell (1924) and Bender (1956) refer to test periods varying from 7 to 60 days for the determination of protein efficiency ratios, and Frost \& Sandy (1949), in a depletion-repletion modification of the growth method, used a 5-day test period followed by 2 days on stock diet, and then 7 days on a protein-deficient diet before another 5 -day test period and a repeat of the cycle.

In all single-period experiments reported here (i.e. tests in which the animals were used for only one test period, at the conclusion of which they were killed for carcass and liver analysis) a protein-deficient diet was given alone for I week, after which supplements of the test food were added daily for another week as outlined above. In the depletion-repletion tests the same animals were used repeatedly according to the scheme outlined by Frost \& Sandy (1949), i.e. 7 days on deficient diet, 5 days on test diet, 2 days on stock diet followed by 7 days on deficient diet, and a repeat of the cycle.

\section{Methods studied}

Nitrogen balance. Based on the ideas of Thomas (1909, I9II), this method was developed by Mitchell and others (Mitchell, 1923-4; Mitchell \& Carman, 1926; Mitchell et al. 1945) and involves the determination of $\mathrm{N}$ in faeces and urine when a known quantity of the protein under test is the sole source of ingested N. When allowance is made for the $\mathrm{N}$ lost during a period of $\mathrm{N}$ starvation, the $\mathrm{N}$ retained can be expressed as a proportion of the $\mathrm{N}$ ingested or absorbed. Collection of faeces and urine is an essential part of this method and metabolism cages are necessary equipment.

The metabolism cages used had a grill-type floor made of glass rods which permitted faeces and urine to pass through to a plastic funnel, slightly larger in diameter than the cage and supported directly below it. A small funnel ( $2 \frac{1}{2}$ in. diameter) with a piece of nylon stocking stretched across the top rested inside the larger one and retained the faeces. Urine passed on through the large funnel and was collected in a $500 \mathrm{ml}$ conical flask.

As a preservative for the urine, a solution consisting of $3 \%(\mathrm{w} / \mathrm{v})$ benzoic acid and 
$0.5 \%(\mathrm{w} / \mathrm{v})$ phenylmercuric nitrate in $50 \%(\mathrm{v} / \mathrm{v})$ ethanol was used. A test to determine the quantity of urine preservative necessary to prevent loss of $\mathrm{N}$ during the period of the tests showed no change in the sample over a 7 -day period when $9 \mathrm{ml}$ of preservative solution were used in a $100 \mathrm{ml}$ sample of urine. Throughout this series of experiments, Io $\mathrm{ml}$ of urine-preservative solution were placed in each collection flask at the beginning of the depletion and test periods. At the end of these periods, the glass grid and the funnels of the metabolism cage were rinsed with water, samples were collected and made to a convenient volume (usually $100 \mathrm{ml}$ ), of which one-fifth was digested for each of duplicate $\mathrm{N}$ determinations. This method of collecting samples was proved satisfactory in a test period during which a portion of the urine was analysed daily and the remainder accumulated until the conclusion of the test, at the end of which analysis of the accumulated sample checked satisfactorily with daily results. The mean value for total $\mathrm{N}$ determined on the accumulated samples was $98 \%$ of that found by analysis of the daily samples.

At the completion of each control and test period, the total quantity of faeces voided (mean wet weight about $7 \mathrm{~g}$ per animal on test and $5 \mathrm{~g}$ on deficient diet) was separated from any hair or particles of food that may have been present and then divided into two approximately equal weighed portions which were each analysed separately for $\mathrm{N}$. Urinary and faecal $\mathrm{N}$ were determined on samples collected during the last 5 days only of both the depletion and test weeks since daily analysis for two sets of twenty-four animals over a 3 -week period showed that 2 days were required for the $\mathrm{N}$ content of urine and faeces to come to equilibrium after a change in diet.

Protein efficiency ratio. First used by Osborne et al. (19r9), this method expresses the biological value of proteins as the gain in weight $(\mathrm{g}) / \mathrm{g} \mathrm{N}$ eaten over a suitable period of time.

A somewhat exhaustive study was made of this method for, although it has been criticized by Mitchell (1944), its simplicity recommends it for routine work. In addition to figures obtained simultaneously with other methods, P.E.R.'s were calculated in a series of fourteen tests carried out separately by adapting Frost \& Sandy's (1949) depletion-repletion method and with both hooded and albino rats. Animals were always weighed at the end of $\mathrm{I}$ week on protein-deficient diet and again at the end of the following week during which they received in addition known amounts of the test food. The effects on the P.E.R. of (I) varying the intake of casein, (2) ad lib. $v$. pair feeding, (3) litter-mate $v$. random grouping, (4) changing the regimen, (5) the previous supplement in depletion-repletion tests, and (6) albino $v$. hooded rats were studied.

Carcass analysis. Fixsen (1934-5) attributes the origin of this method to McCollum \& Shukers many years ago, and it has since been used by some other workers. It involves the estimation of the total $\mathrm{N}$ content of the carcass of test animals.

Three groups of animals were selected for this experiment and all were given a protein-deficient diet for $\mathrm{I}$ week. At the end of this time, animals of one group (controls) were killed and their $\mathrm{N}$ content was determined. Animals of the other groups were weighed and their $\mathrm{N}$ content was calculated from the values found for the control group, it being assumed that the percentage of $\mathrm{N}$ in all animals at this 
stage of the test would be the same. Rations containing the test foods at a level of about 10\% protein were then given to the test groups for I week, at the end of which these animals were killed and analysed. Subtraction of the value for body $\mathrm{N}$ calculated at the beginning of the test period from that found at its end gave $\mathrm{N}$ retained from the food eaten.

Brush, Willman \& Swanson (1947), Murray (1948) and Forbes \& Yohe (1955) all minced carcasses before digesting them for protein determination. This is an unpleasant and time-consuming procedure, and attention was given to the development of a more satisfactory method. Excellent results were obtained when the whole animal, including the blood but without the contents of the alimentary tract, was placed in a I 1. conical flask, $200 \mathrm{ml}$ conc. $\mathrm{H}_{2} \mathrm{SO}_{4}$ were poured over it and some ro min later $200 \mathrm{ml}$ water were cautiously added. Disintegration of the carcass began immediately on addition of the water, and digestion was well advanced in $\mathrm{I} h$ without the application of any external heat. After they had stood overnight at room temperature, samples in the flasks were autoclaved for $3 \mathrm{~h}$ at $\mathrm{I} 6 \mathrm{lb} / \mathrm{in}^{2}$. Hydrolysates were made up to I $\mathrm{l}$. and portions taken for $\mathrm{N}$ determinations. Bender \& Miller (1953) and Miller \& Bender (1955) have recently introduced a modification of the procedure in which the water content of the carcass is determined and $\mathrm{N}$ estimated from it by use of a predetermined factor. The method has been studied by Dreyer (1957) but was not used during this investigation.

Values by the carcass-analysis method were obtained for six animals on each of two diets, one containing casein and the other gluten, mixed with basal ration so that the mixture contained about $\mathrm{r} \cdot 75 \% \mathrm{~N}$. Shortage of cages made it necessary to house the animals for this test in groups of six, and values for these animals had to be pooled.

Nitrogen content of liver. Kosterlitz (1944) has suggested that the sensitivity with which the $\mathrm{N}$ content of the liver responds to different dietary proteins may be used as the basis of a method for determining the nutritive value of proteins, and such a procedure was outlined by Henry et al. (1953). In my work, one of several similar groups of rats was selected as control. At the end of the depletion period, all animals were weighed and those in the control group were stunned with a sharp blow on the head and decapitated immediately so that they bled freely. Livers were removed as rapidly as possible after opening the abdomen, dried on filter-paper and weighed on an automatic balance. Duplicate portions of about $\mathrm{I} g$ were taken for $\mathrm{N}$ estimation, and the $\mathrm{N}$ found was calculated as liver $\mathrm{N}(\mathrm{mg}) / \mathrm{roo} \mathrm{g}$ body-weight. Liver $\mathrm{N}$ of all groups at the end of the depletion period was assumed to be the same as that of the controls. Animals in the other groups then received daily weighed supplements of the foods under test in addition to the basal diet. After I week they too were killed and their livers analysed for $\mathrm{N}$. From the value for $\mathrm{N}$ expressed as $\mathrm{mg} / \mathrm{roo} \mathrm{g}$ original bodyweight of the animals (weight at the end of the depletion period), the value for the control group was subtracted and the result assumed to give the increase, during the test period, in liver $\mathrm{N} / \mathrm{roo} \mathrm{g}$ original body-weight for the test groups.

Chemical score. The essential amino-acid content of a protein has been suggested by Mitchell \& Block (1946) as a means of estimating its biological value. The 'chemical score method', as it has been called, requires an accurate analysis of the protein 
under test for nine essential amino acids, in order to determine the most deficient of them in relation to whole-egg protein which has been shown to be almost $100 \%$ utilized (Mitchell \& Carman, 1926; Sumner, 1938) and is regarded as the ideal standard. 'The percentage deficiency, relative to whole-egg protein, of the most deficient amino acid is then subtracted from 100 to give a value called the chemical score. Mitchell \& Block (1946) plotted biological values calculated from N-balance values against percentage deficiency of the most deficient amino acid for twenty-three widely different protein foods and from the relationship obtained derived the regression equation:

$$
Y=102-0.634 x
$$

in which $Y=$ biological value and $x=$ the percentage deficiency of the most deficient amino acid.

Creatinine: nitrogen ratio in urine. The use of this ratio as a means of measuring the biological value of proteins was reported by Murlin et al. (1948) and Murlin, Hayes \& Johnson (1953). Metabolism cages are necessary for the collection of urine from which the faeces must be separated, so in effect the same equipment as is used for N-balance determinations is required. The urine collected is made up to a convenient volume (usually $100 \mathrm{ml}$ ), and portions are analysed for $\mathrm{N}$ and creatinine. The method is based on the idea that since creatinine excretion is constant in quantity regardless of diet, and more $\mathrm{N}$ is excreted from poor-quality than from good-quality proteins, the ratio creatinine $\mathrm{N}$ : total $\mathrm{N}$ in the urine will vary directly as the biological value of the protein being eaten. Values reported here are in terms of creatinine (mg): total $\mathrm{N}(\mathrm{g})$, since this ratio is proportionate to that for creatinine $\mathrm{N}$ : total $\mathrm{N}$ and its use eliminates one calculation.

Table 2. Microbiological methods used for estimation of amino acids

\begin{tabular}{|c|c|c|c|c|}
\hline \multirow[b]{2}{*}{ Amino acid } & \multirow[b]{2}{*}{ Organism } & \multirow[b]{2}{*}{$\begin{array}{l}\text { Hydrolysing } \\
\text { solution }\end{array}$} & \multicolumn{2}{|c|}{$\begin{array}{c}\text { No. of independent } \\
\text { assays* }\end{array}$} \\
\hline & & & Casein & Gluten \\
\hline Cystine & Lactobacillus arabinosus, & & 3 & 3 \\
\hline Histidine & Leuconostoc mesenteroides & & 3 & 3 \\
\hline Isoleucine & Lb. arabinosus & & 3 & 3 \\
\hline Leucine & Lb. arabinosus & & 3 & 3 \\
\hline Lysine & Leuc, mesenteroides & $2.5 \mathrm{~N}-\mathrm{HCl}$ & 3 & 3 \\
\hline Methionine & Leuc. mesenteroides & & 2 & 3 \\
\hline Phenylalanine & Leuc. mesenteroides & & 2 & 3 \\
\hline Threonine & Streptococcus faecalis $\mathrm{R}$ & & 3 & 3 \\
\hline Tryptophan & Lb. arabinosus & $\begin{array}{l}38 \%(\mathrm{w} / \mathrm{v}) \\
\text { barium } \\
\text { hydroxide }\end{array}$ & $\mathbf{I}$ & I \\
\hline Valine & Lb. arabinosus & $2.5 \mathrm{~N}-\mathrm{HCl}$ & 3 & 3 \\
\hline
\end{tabular}

* Three replicate determinations were done on each hydrolysate. Samples were hydrolysed for $7 \mathrm{~h}$.

\section{Analytical procedures}

Nitrogen. All $\mathrm{N}$ determinations were done by the Kjeldahl-Wilfarth-Gunning method. Portions of urine were digested directly, but $25 \mathrm{ml}$ water were added to faeces samples some minutes before the concentrated sulphuric acid, as this procedure was found to facilitate digestion considerably. The ammonia was distilled into $100 \mathrm{ml}$ 
$4 \%(\mathrm{w} / \mathrm{v})$ boric acid and titrated with $0.45 \mathrm{~N}^{-} \mathrm{H}_{2} \mathrm{SO}_{4}$. The boric acid contained $2 \%$ $(\mathrm{v} / \mathrm{v})$ of indicator made up by mixing one part of methyl red (B.P.) with five parts bromocresol green (B.P.)

Creatinine. The method of Clark \& Thompson (1949) was used in the determination of creatinine. Absorption was measured in a Unicam S.P. 350 spectrophotometer or a Bausch and Lomb Spectronic 20 spectrophotometer.

Amino acids. The essential amino acids were determined by the microbiological methods of Barton-Wright (1946) (see Table 2).

Table 3. Mean values with their standard errors obtained in the assessment of protein quality by different methods

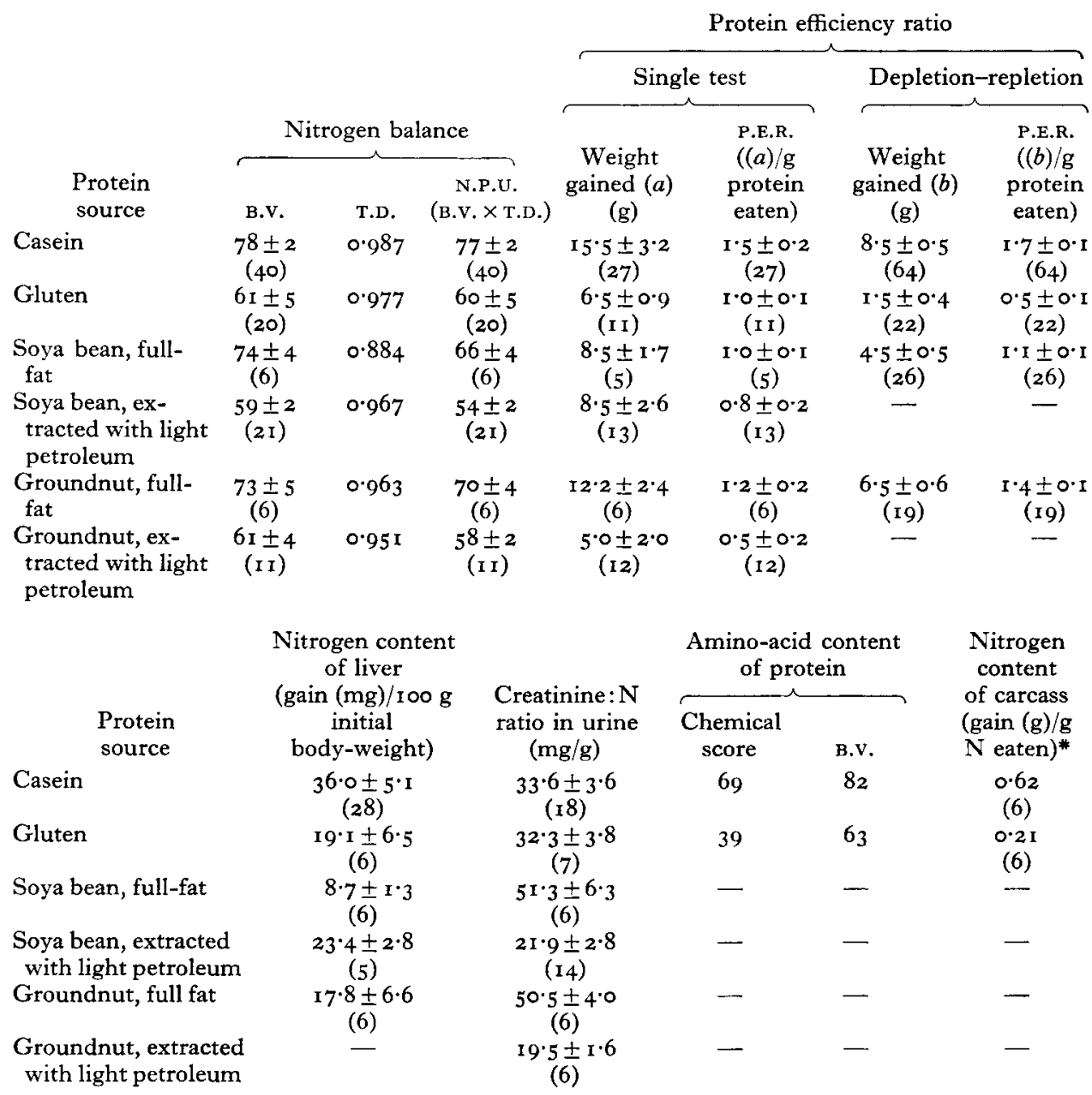

B.V., biological value; T.D., true digestibility; N.P.U., net protein utilization; P.E.R., protein efficiency ratio.

Figures in parentheses are the numbers of animals included in the tests to obtain the mean figures quoted.

* These figures were obtained from totals for the six animals and therefore no standard error could be calculated. 


\section{RESULTS AND DISCUSSION}

For the sake of clarity, results are discussed according to the criterion by which the protein value of the foods examined was judged and values are assembled in Tables 3 and 4 for ready comparison of results obtained by different criteria for different proteins. The number of animals used in calculating the mean values reported is shown in parentheses in Table 3 .

\section{Nitrogen balance}

The determination of biological value by this method was found to be a straightforward procedure which gave satisfactory uniformity and involved no particular difficulties once the metabolism cages were made and set up.

Effect of varying intake. Morgan (I931), Fixsen \& Jackson (1932), Chick, BoasFixsen, Hutchinson \& Jackson (I935) and Henry \& Kon (1957) have noted that the greater the quantity of a protein eaten by the test animals, the lower is the biological value indicated, and that this relationship holds for a number of different foods.

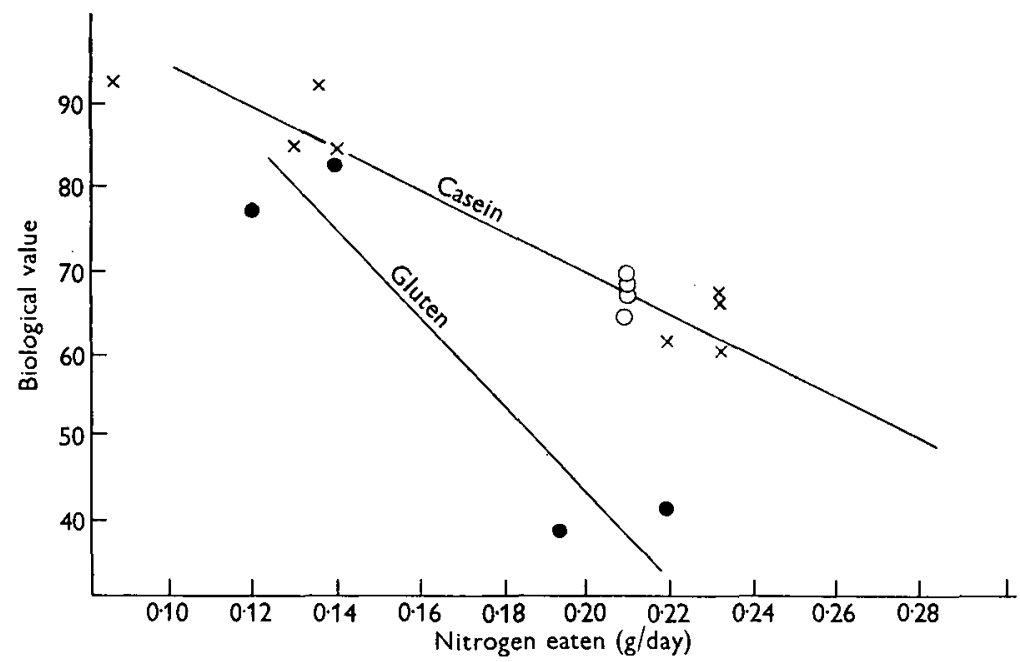

Fig. 1. Curves showing reduction in biological value of proteins for rats with increased nitrogen intake. $x$, biological values for casein, each calculated from results for six animals given daily the quantity of $\mathrm{N}$ shown; $\mathrm{O}$, values of Metta \& Mitchell (1956) for casein; $\boldsymbol{\theta}$, biological values for gluten each calculated from results for six animals given daily the quantity of $\mathrm{N}$ shown.

This study confirms these observations as shown graphically in Fig. 1 . Casein was given at levels ranging from 0.13 to $0.23 \mathrm{~g} \mathrm{~N}$ /day and the change in response was obvious. The only set of figures found in the literature reporting both biological value and rate of $\mathrm{N}$ intake for casein was published by Metta \& Mitchell (1956) and fits well the curve obtained from the results of this investigation.

In view of this phenomenon it is not easy to determine what quantity of a protein should be given to test animals in order that biological values calculated from their response may be truly comparable. Merely giving equal amounts of protein does not necessarily overcome the difficulty. If, for example, equal quantities of casein and 
Vol. 13

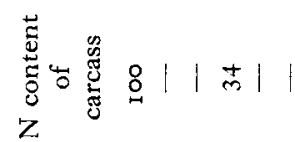

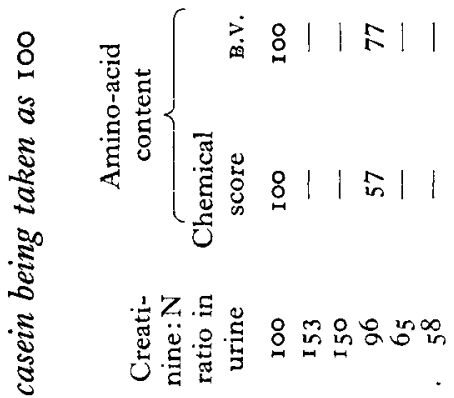

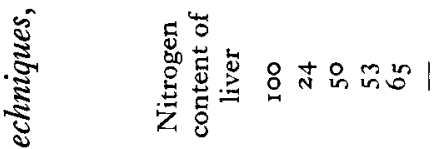

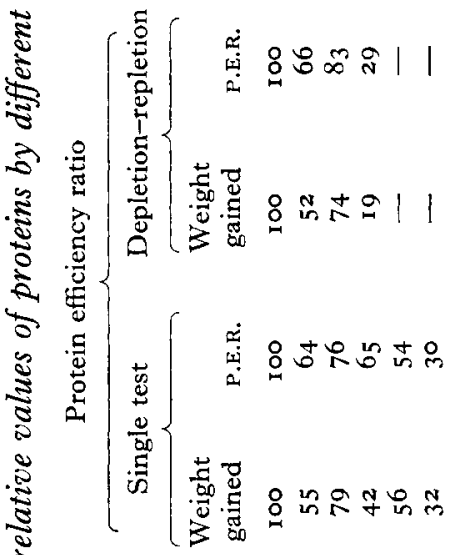

نัّ

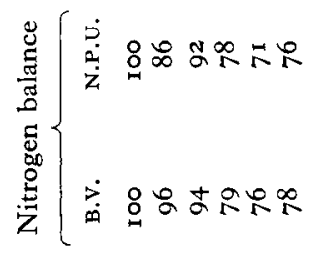

舫

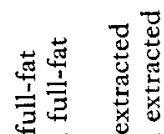

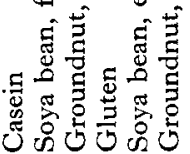


gluten were offered, animals receiving the latter would be in a lower state of $\mathrm{N}$ nutrition than the others, and might be expected to use more efficiently the $N$ available. Hence the $\mathrm{N}$ retention from gluten, though lower than that from casein, would nevertheless be higher than if it were utilized with only the same degree of efficiency as casein. However, no more satisfactory alternative to offering diets of equal $\mathrm{N}$ content is at present available and, since any difference in biological value between two proteins appears to increase as the quantity of protein given increases up to $0.22 \mathrm{~g} \mathrm{~N} /$ day (see Fig. I), supplements of test food containing $0.20-0.25 \mathrm{~g} \mathrm{~N}$ offered daily should make the test more sensitive than with smaller quantities of $N$. A further increase in sensitivity might be achieved if greater quantities of $\mathrm{N}$ were eaten but the ability of the animals to eat greater quantities of all foods likely to be tested would need to be proved.

Metabolic nitrogen. In all experiments, the $\mathrm{N}$ excreted on a $\mathrm{N}$-free diet was determined for each group of animals during I week immediately before the beginning of the test period. The results showed that, with litter-mate groups of about equal weight, the metabolic faecal $\mathrm{N}$ for each group was almost the same, but in tests with animals randomly chosen, even though weights again were about equal, the quantities of $\mathrm{N}$ eliminated by two groups on the deficient diet differed considerably. The variance estimate for litter-mates was significantly smaller at the $\mathrm{I} \%$ level than that for random groups. On the other hand, metabolic urinary $\mathrm{N}$ showed no uniformity between groups of animals of about equal weight and age whether or not they were litter-mates; the variance estimate for litter-mates was not significantly different at the $5 \%$ level from that for random groups. There was a wide variation between animals of different ages, and calculation on a body-weight basis of excreted $\mathrm{N}$ did not reduce the variability. It is clear that each test needs to be preceded by a control period during which metabolic faecal and urinary $\mathrm{N}$ is determined individually on each animal to be used.

\section{Protein efficiency ratio}

Effect of varying protein intake. In this work, different groups were given, in addition to the basal diet, supplements of casein in such quantities that seven groups received $0.87 \mathrm{~g}$ and two groups $\mathrm{I} \cdot 74 \mathrm{~g}$ protein/day in depletion-repletion tests. The difference between P.E.R.'s for these levels of feeding was not significant $(P>0 \cdot \mathrm{I})$. In single-period experiments, two groups received $0.86 \mathrm{~g}$ protein/day and two groups $\mathrm{I} \cdot 47 \mathrm{~g} /$ day and again the difference between P.E.R.'s was not significant $(P>0.8)$.

Ad lib. v. pair feeding. Animals fed ad lib. received diets in which casein or gluten was mixed with the basal diet to give about $10 \%$ protein in the mixture. Results obtained by ad lib. feeding of both casein and gluten were higher than those for pairfeeding tests, but the increase for casein was much greater than for gluten. There was good agreement between two ad lib. tests with casein carried out several months apart, one giving $2.6 \mathrm{~g}$ and the other $2.8 \mathrm{~g}$ gain in weight $/ \mathrm{g}$ protein eaten. The value obtained for gluten in an $a d$ lib. test was I. I g gain/g protein eaten, or about $4 \mathrm{I} \%$ of the mean value for casein. By pair-feeding tests, the mean for casein was $I \cdot 2$ and for gluten $0.8 \mathrm{~g}$ gain $/ \mathrm{g}$ protein eaten, or $67 \%$ of the casein value. This tendency for the difference 
between two proteins to be increased in ad lib. tests confirms the findings of Barnes, Maack, Knights \& Burr (1945) who noted that poorer-quality proteins are penalized in results from $a d l i b$. feeding at the $10 \%$ level The most satisfactory P.E.R. resulted from the giving of equal quantities of $\mathrm{N}$ to all animals, either in diets containing the test food in sufficient quantity to give a protein content of about $10 \%$ in the mixture or in separate weighed supplements of the test food containing $\mathrm{I} \cdot 0-\mathrm{I} \cdot 5 \mathrm{~g} \mathrm{~N} / \mathrm{week} /$ animal in addition to the protein-deficient diet $a d$ lib. This finding is in agreement with those of Mitchell (1944) and also those of Harte, 'Travers \& Sarich (1947).

Litter-mate v. random grouping. In order to compare the relative effectiveness of litter-mate and random groups for determining P.E.R., this value was calculated for three groups of four rats given casein (I g/day) in addition to protein-free diet ad lib. In one group the rats were randomly selected and were not related to rats in the other two groups, in which the animals in one were litter-mates of those in the other. The mean P.E.R.'s were calculated for two consecutive test periods with each group. Values for the litter-mate groups were $1 \cdot 7 \pm 0 \cdot 1$ and $r \cdot 3 \pm 0.3$, and for the random group $I \cdot 7 \pm 0 \cdot \mathrm{I}$. This comparison shows as much difference between the two littermate groups as between either of these and the random group. Further comparisons would need to be made before final conclusions can be drawn, but this test indicates that nothing is gained by using litter-mate groups.

Effect of different regimens. The mean P.E.R. for casein by single tests (omitting those for ad lib. feeding which are shown above to be of an entirely different order of values) was $1 \cdot 2 \pm 0 \cdot 2$, and by depletion-repletion tests it was $1 \cdot 5 \pm 0 \cdot 2$. The mean for gluten was $0.9 \pm 0.1$ and $0.5 \pm 0.1$, respectively, by the two methods. Thus the depletionrepletion procedure emphasizes the difference between casein and gluten in protein quality, as it gives higher P.E.R. values for the former, and lower for the latter. The lack of agreement between the two methods was probably due to the different treatments given to the animals before the beginning of the test period. The single-test animals were transferred from stock to protein-deficient diet for I week before test, but depletion-repletion animals were used repeatedly in the 2-weekly cycle: 7 days protein-deficient -5 days test- 2 days stock -7 days deficient, and so on. That changes in the preparatory diet have a bearing on test results was noted by Bosshardt, Ydse, Ayres \& Barnes (1946) who found considerable variation in P.E.R. of casein calculated for animals receiving different diets before going on to test, and Calloway \& Spector (1955) found that during calorie restriction the negative $\mathrm{N}$ balance was directly proportional to the amount of $\mathrm{N}$ given during standardization before the test. In any event it seems that P.E.R.'s are only comparable when calculated from results with animals given strictly uniform treatment throughout both pre-test and test periods.

Influence of previous supplement in depletion-repletion tests. A matter of considerable interest was the consistently greater growth response of animals transferred from gluten to casein in the course of the depletion-repletion series (mean P.E.R. $2 \cdot 3 \pm 0 \cdot 6$ ) compared with that of animals receiving casein in consecutive tests (mean P.E.R. $\mathrm{r} \cdot 6 \pm 0.3$ ) even though test periods were always separated by 2 days on stock diet and 7 days of protein starvation. 
It would seem then that, in depletion-repletion tests in which different foods are being examined, a longer period on stock diet than the 2 days recommended by Frost \& Sandy (1949) and used in this investigation should be allowed for the equilibration of the animals between tests. A 4-weekly cycle giving I week on each of stock, deficient, stock and test diets in that order should be satisfactory. Although the proteins tested were grouped in somewhat the same order of quality by P.E.R. as by $\mathrm{N}$ balance, variations between different tests for one food were greater, and the method would therefore appear to be less reliable.

Hooded v. albino rats. The results from four separate tests with hooded rats given I $g$ casein/day were pooled as were those from three separate tests with albinos on the same diet. Mean P.E.R. calculated for the twenty-six hooded animals was $I \cdot 4 \pm 0 \cdot 2$ compared with $1 \cdot 6 \pm 0.2$ for the twelve albinos. This difference is not significant $(P>0 \cdot 2)$.

\section{Carcass analysis}

Values obtained for net protein utilization (N.P.U.) by this method were $62 \%$ for casein and $21 \%$ for gluten. Figures from which these values were calculated are given in Table 5. The value for gluten seemed too low when compared with results by other methods, and that for casein was also lower than balance-sheet results would indicate. It was probably so because animals in this test were given food ad lib. and consumed about eight times the quantity of $\mathrm{N}$ eaten in the $\mathrm{N}$-balance tests. The drop in biological value (and consequently in N.P.U.) which accompanies increased $N$ intake is discussed on p. $25^{\circ}$.

Table 5. Net protein utilization calculated from results of carcass analysis of rats

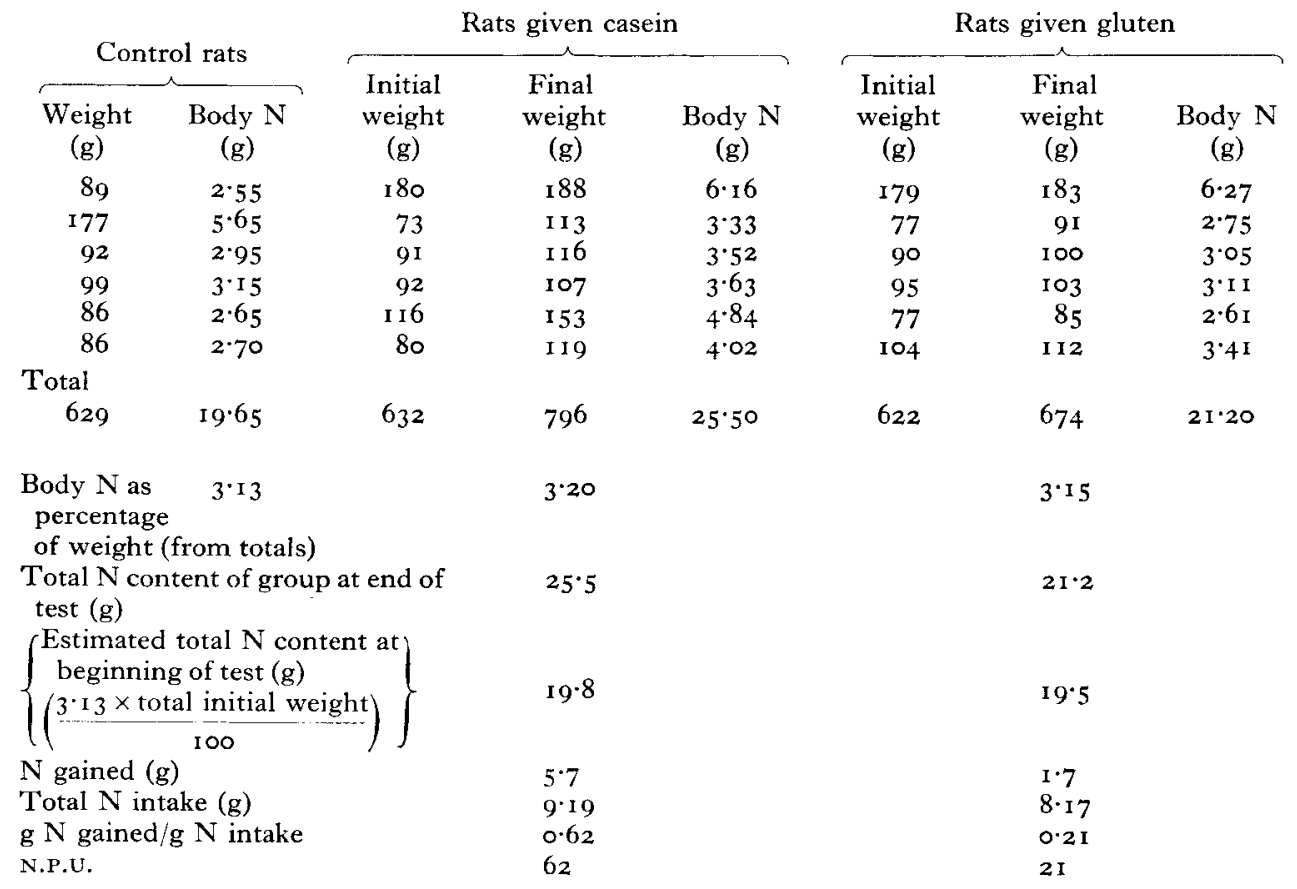


The N.P.U. values which are obtained from carcass analysis can also be found by the $\mathrm{N}$-balance method, which although involving twice as many $\mathrm{N}$ estimations (for urine and for faeces instead of for carcass only) has the advantages of simplicity in the preparation of samples and of the possibility of using the animals repeatedly.

Bender \& Miller's (I953) suggestion that water be determined instead of $\mathrm{N}$ and that a predetermined ratio of water: $\mathrm{N}$ be used in calculating the $\mathrm{N}$ content of carcasses is based on Moulton's (1923) claim that the $\mathrm{N}$ and water contents are a constant proportion of the body-weight when measured on a fat-free basis. However, for young rats prepared in a uniform way for protein tests, it would seem just as reasonable to work from the premise that $\mathrm{N}$ is a constant proportion of the body, determine that proportion on representative animals after uniform treatment through a control period of $I$ week and use the percentage found to calculate the $\mathrm{N}$ content of test animals from their body-weights at the beginning and end of the test period without need to destroy the animals. The figures in Table 6 were used to test this hypothesis. The percentage of $\mathrm{N}$ in the bodies of the rats on the different diets used was fairly constant throughout, indicating that the weight gained by the animals on test contained about the same proportion of $\mathrm{N}$ as was found in the control rats. The value $(3.13 \%)$ found for the $\mathrm{N}$ content of the control animals was used to convert weight gained on the test diets into $N$ gained, which, divided by the $N$ intake, gave the N.P.U. expressed as a decimal. The N.P.U.'s so calculated were little different from those obtained by carcass analysis, as is demonstrated in Table 6. There was good agreement between the values for gluten, and with casein the difference was about $9 \cdot 7 \%$ of the value obtained by actual $\mathrm{N}$ estimation. Bender \& Miller (1953) obtained differences for N.P.U. by the waterdetermination and $\mathrm{N}$-determination methods amounting to as much as $14.5 \%$ of the result by the analysis for $\mathrm{N}$. The results in Table 5 were obtained by offering ad lib. diets containing the protein-deficient mixture with the test food added to give about 10\% protein. As noted earlier (p. 253) different values may be expected if other feeding methods are used.

Table 6. Net protein utilization calculated from body-weight gains of the test rats and the nitrogen content of controls

(Values for six rats)

\begin{tabular}{|c|c|c|c|c|c|c|}
\hline \multirow[b]{3}{*}{ Protein source } & \multirow[b]{3}{*}{$\begin{array}{l}\text { Weight } \\
\text { gain }(g)\end{array}$} & \multirow[b]{3}{*}{$\begin{array}{l}N \text { intake } \\
\text { (g) }\end{array}$} & & & \multicolumn{2}{|c|}{ Net protein utilization } \\
\hline & & & \multicolumn{2}{|c|}{$N$ gain } & \multirow{2}{*}{$\begin{array}{l}\text { From } \\
\text { body- } \\
\text { weight }\end{array}$} & \multirow{2}{*}{$\begin{array}{c}\text { By } N \\
\text { deter- } \\
\text { mination }\end{array}$} \\
\hline & & & $\mathrm{g}^{*}$ & $\mathrm{~g} / \mathrm{g}$ intake & & \\
\hline Casein & 164 & 9.19 & $5 \cdot 14$ & 0.56 & $5^{6}$ & 62 \\
\hline Gluten & 52 & $8 \cdot 17$ & $I \cdot 63$ & 0.20 & 20 & $2 \mathrm{I}$ \\
\hline
\end{tabular}

It must be kept in mind that in rats from other laboratories prepared under other conditions the proportion of $\mathrm{N}$ in the carcass may be different. For example, Mitchell, Burroughs \& Beadles ( 1936 ) found that the $N$ content of rats fed on diets containing 
either beef or pecan-nut proteins was 3.05 and $3.04 \%$ respectively, and McClure, Voris \& Forbes (1934) report a mean N content of $3.4^{2}$ and $3.38 \%$ for groups of eleven rats on thiamine-deficient and supplemented diets respectively.

In the experiment reported here, rats on protein-free diet, casein supplement, and gluten supplement contained $3 \cdot 13,3 \cdot 20$ and $3 \cdot 15 \% \mathrm{~N}$ respectively. These values, together with those found by Mitchell $e t$ al. and McClure $e t$ al. quoted above, illustrate the variation to be expected between different colonies of rats and at the same time indicate a satisfactory degree of uniformity in any one colony even among rats receiving very different diets. This conclusion supports the feasibility of using percentage $\mathrm{N}$ and body-weight gained to calculate body $\mathrm{N}$ gained during a test period. However, such a procedure is not recommended to replace carcass analysis or $\mathrm{N}$-balance studies but is suggested as a simpler and perhaps equally accurate alternative to the $\mathrm{H}_{2} \mathrm{O}: \mathrm{N}$ ratio method of determining body $\mathrm{N}$.

Carcass analysis does not recommend itself for use in a regular way because (I) animals can be used for one test only, (2) the killing and digestion of the animals is unpleasant and time-consuming when many carcasses are involved and autoclave space is limited, and (3) it has no advantage over other methods.

This method could, however, be very helpful in a laboratory where no metabolism cages are available for the collection of urine and faeces and where a few determinations of protein quality in terms of N.P.U. need to be carried out at infrequent intervals. In other circumstances, the installation of metabolism cages would seem to be warranted if N.P.U. values are to be estimated.

\section{Liver nitrogen}

For intakes of from 0.12 to $0.24 \mathrm{~g} \mathrm{~N} /$ day, little relationship appeared to exist between the quality of the protein given and the increase in liver $\mathrm{N}$ that followed its ingestion.

The calculation of results by this method requires the assumption that a value for liver $\mathrm{N}$ found at the end of a control period for one group of rats can be applied to another test group, and its validity is open to question. For example, liver $\mathrm{N} / \mathrm{ro0} \mathrm{g}$ body-weight for different control groups of animals of about the same age and weight varied between $\mathrm{g}^{\mathrm{I}}$ and I I I $\mathrm{mg}$. This $20 \mathrm{mg}$ difference between controls was more than half the mean increase in liver $\mathrm{N}(36 \mathrm{mg} / \mathrm{r} 00 \mathrm{~g}$ body-weight) noted for the best protein tested (casein). Since similar differences in liver $\mathrm{N}$ may exist between test groups at the beginning of a test period, the validity of assuming them to be all the same is open to serious question. The use of litter-mate groups may reduce this variability, but further work was not done by this method because the drawbacks noted for carcass analysis apply also to it.

\section{Chemical score}

Only two diets were evaluated by this method. Three separate samples of the diet containing gluten as the only source of protein were analysed for nine of the ten essential amino acids and cystine, tryptophan being determined in one sample only. Two separate samples of the casein diet were assayed for phenylalanine and methio- 
Vol. 13

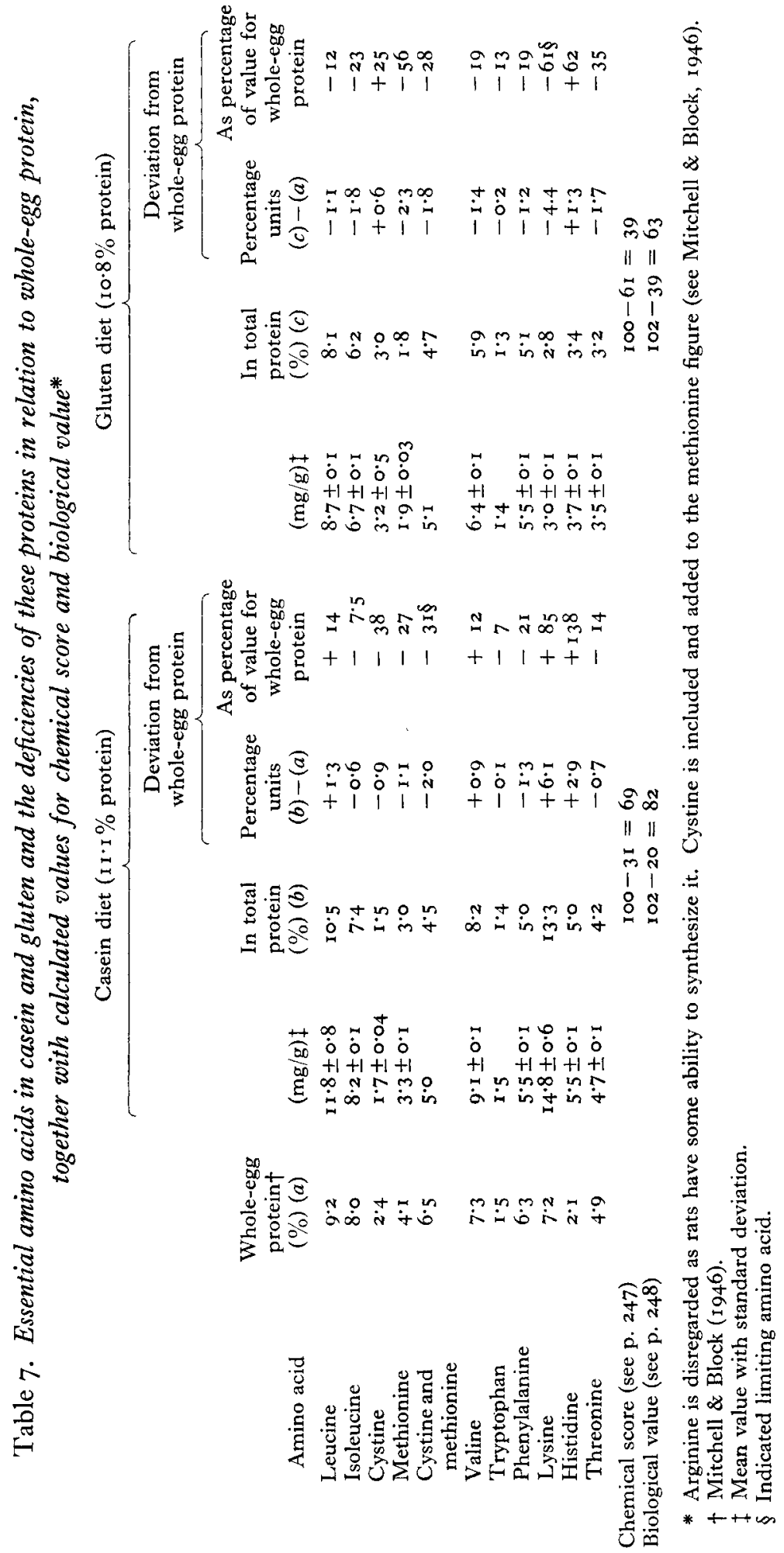


nine. Tryptophan was determined in one sample and the other seven acids in three separate samples. Mean values found and scores calculated from them are set out in Table 7 .

Biological values calculated from the figures in Table 7 with the regression equation of Mitchell \& Block (1946) (see p. 248) were $82 \%$ for casein and $63 \%$ for gluten. These values agree reasonably well with those found in N-balance tests $(78$ and $61 \%)$.

Unfortunately, errors may be introduced into the method in a number of ways. For example (I) the biological value of soya-bean protein is improved greatly by germination of the bean as shown by Everson, Steenbock, Cederquist \& Parsons (1944), but Block \& Bolling (1944), by chemical analysis, could find no change in the content of limiting essential amino acids (cystine and methionine) in the germinated seed; (2) the requirement of the animal for certain amino acids may be different with diets containing different proteins as demonstrated by Sauberlich \& Salmon (I955) in the study of tryptophan imbalance; (3) the presence of one amino acid in excess of requirement can increase the requirement for another as shown by Harper, Monson, Benton \& Elvehjem (1953), and also reported by Elvehjem (1956). It would seem, then, that consideration of the most deficient amino acid in a protein is not of itself sufficient as a guide to the nutritive quality of that protein since calculations based on it may be completely invalidated by the proportions of the other amino acids present, or by changes in a protein that do not affect its amino-acid content.

\section{Creatinine:nitrogen ratio}

The determination of creatinine is a simple and rapid procedure, but the ratios calculated lacked uniformity. This was due in part to the variations in creatinine excretion by the animals at different ages, animals 8 weeks and those I year old excreting less in this experiment than those in the prime of life (20 weeks). There appeared to be some relation between this ratio and the quality of the protein, though the correlation with biological value reported by Murlin et al. (1953) from experiments on dogs was not found. The method requires that urinary $\mathrm{N}$ and creatinine be determined. It involves rather less analytical work than the $\mathrm{N}$-balance procedure in which urine and faeces both have to be analysed for $\mathrm{N}$, but the same equipment in the form of metabolism cages is necessary and, in view of the influence exerted on the results by such factors as the age of the animals used, it would seem advisable to omit the creatinine determination, carry out the estimation of $\mathrm{N}$ of the faeces instead, and thus gain information which would make possible the calculation of not only biological values but also digestibility and N.P.u. figures.

\section{SUMMARY}

r. Protein quality has been estimated from ( $\mathrm{I}$ ) nitrogen-balance methods, (2) change in body-weight and protein efficiency ratios, (3) changes in carcass N, (4) changes in liver $\mathrm{N},(5)$ analysis of the protein for amino acids, and (6) changes in the creatinine: $\mathrm{N}$ ratio in urine. Male albino and hooded rats were used for methods (I)-(4) and (6). Amino acids were determined microbiologically. 
2. Measurement of $\mathrm{N}$ balance by the balance-sheet method seemed the most reliable provided (I) $\mathrm{N}$ intake was maintained at the same level for all tests and (2) the metabolic faecal and urinary $\mathrm{N}$ of the test animals were determined before each test. In addition to biological value, this method also makes available other useful values such as net protein utilization and true digestibility.

3. If B.v. by $\mathrm{N}$ balance is accepted as standard then, excluding N.P.U. which is derived from B.V., the method giving the rank order best correlated with B.V. was P.E.R. by the depletion-repletion method, but results were not nearly as reproducible as those by N-balance methods. Results for depletion-repletion tests indicated that a 2-weekly cycle was too short. A 4-weekly cycle is recommended.

4. Analysis of carcass for $\mathrm{N}$ gave satisfactory N.P.U. but did not offer any advantages over the balance-sheet method and in regular use would require more animals since the animals must be destroyed at the end of each test.

5. Liver $\mathrm{N}$ appeared to be unreliable as a measure of protein quality. Dependability might be improved by using litter-mates but this procedure was not tried, as the method has no advantages over the balance-sheet method.

6. The analysis of casein and gluten for their essential amino-acid content gave chemical scores which agreed well with those from N-balance tests. Factors which may invalidate results by this method are mentioned.

7. The determination of the creatinine: $\mathrm{N}$ ratio in the urine is simple, but extraneous factors such as the age and condition of the animals used appeared to have a marked bearing on the results.

8. There was no significant difference between results from hooded rats and those from albinos $(P>0 \cdot 2)$.

\section{REFERENCES}

Barnes, R. H., Maack, J. E., Knights, M. J. \& Burr, G. O. (1945). Cereal Chem. 22, 273.

Barton-Wright, E. C. (1946). Practical Methods for the Microbiological Assay of the Vitamin B Complex and Essential Amino Acids. London: Ashe Laboratories Ltd.

Bender, A. E. (1956). Brit. F. Nutr. 1o, 135.

Bender, A. E. \& Miller, D. S. (1953). Biochem. F. 53, vii.

Block, R. J. \& Bolling, D. (1944). F. Amer. diet. Ass. 20, 69.

Bosshardt, D. K., Ydse, L. C., Ayres, M. M. \& Barnes, R. H. (1946). F. Nutr. 31, 23.

Brush, M., Willman, W. \& Swanson, P. O. (1947). F. Nutr. 33, 389.

Calloway, D. H. \& Spector, H. (1955). F. Nutr. 57, 73.

Chick, H., Boas-Fixsen, M. A., Hutchinson, J. C. D. \& Jackson, H. M. (1935). Biochem. F. $29,1712$.

Clark, L. C. Jr. \& Thompson, H. L. (1949). Analyt. Chem. 2r, 1218.

Cuthbertson, D. P., McCutcheon, A. \& Munro, H. N. (1940). Biochem. F. 34, 1002.

Dreyer, J. J. (1957). Brit. F. Nutr. 11, 22.

Elvehjem, C. A. ( 1956). F. Amer. diet. Ass. 32, 305.

Everson, G. J., Steenbock, H., Cederquist, D. C. \& Parsons, H. T. (1944). F. Nutr. $27,225$.

Fixsen, M. A. B. (1934-5). Nutr. Abstr. Rev. 4, 447.

Fixsen, M. A. B. \& Jackson, H. M. (1932). Biochem. F. 26, 1923.

Forbes, R. M. \& Yohe, M. (1955). F. Nutr. 55, 493.

Frost, D. V. \& Sandy, H. R. (1949). F. Nutr. 39, 427.

Harper, A. E., Monson, W. J., Benton, D. A. \& Elvehjem. C. A. (1953). F. Nutr. 50, 383.

Harte, R. A., Travers, J. J. \& Sarich, P. (1947). F. Nutr. 34, 363.

Henry, K. M. \& Kon, S. K. (I957). Brit. F. Nutr. II, 305.

Henry, K. M., Kosterlitz, H. W. \& Quenouille, M. H. (1953). Brit. F. Nutr. 7, 5 r.

Hoagland, R. \& Snider, G. G. (1926). F. agric. Res. 32, 1025.

Holemans, K. \& Lambrechts, A. (1955). F. Nutr. 56, 477.

Kosterlitz, H. W. (1944). Nature, Lond., 154, 207.

McClure, F. J., Voris, LeR. \& Forbes, E. B. (1934). F. Nutr. 8, 295. 
Metta, V. C. \& Mitchell, H. H. (1956). F. Nutr. 59, 50 I.

Miller, D. S. \& Bender, A. E. (1955). Brit. F. Nutr. 9, $3^{82 .}$

Mitchell, H. H. (1923-4). F. biol. Chem. 58, 873 .

Mitchell, H. H. (1924). Physiol. Rev. 4, 424.

Mitchell, H. H. (1944). Industr. Engng Chem. (Anal.), 16, 696.

Mitchell, H. H. \& Block, R. J. (1946). F. biol. Chem. 163, 599.

Mitchell, H. H., Burroughs, W. \& Beadles, J. R. (1936). F. Nutr. Ir, 257.

Mitchell, H. H. \& Carman, G. G. (1926). F. biol. Chem. 68, I83.

Mitchell, H. H., Hamilton, T. S. \& Beadles, J. R. (1945). F. Nutr. 29, 13.

Morgan, A. F. (1931). F. biol. Chem. 90, 77I.

Moulton, C. R. (1923). F. biol. Chem. 57, 79.

Murlin, J. R., Hayes, A. D. \& Johnson, K. (1953). F. Nutr. 5I, I 49.

Murlin, J. R., Szymanski, T. A. \& Nasset, E. C. (1948). F. Nutr. 36, I 7 I.

Murray, H. C. (1948). F. Nutr. 35, 257.

Osborne, T. B. \& Mendel, L. B. (1917). F. biol. Chem. 32, 369.

Osborne, T. B., Mendel, L. B. \& Ferry, E. L. (1919). F. biol. Chem. 37, 223.

Rubner, M. (1879). Z. Biol. 15, I 15.

Sauberlich, H. E. \& Salmon, W. D. (1955). F. biol. Chem. 214, 463.

Sumner, E. E. (1938). $\mathcal{~}$. Nutr. 16, 129.

Thomas, K. (1909). Arch. Anat. Physiol. Lpz. Physiol. Abt. p. 219.

Thomas, K. (19г I). Arch. Anat. Physiol. Lpz. Physiol. Abt. Suppl. p. 249.

\title{
Hyperphagia and gastric hypertrophy in rats adapted to intermittent starvation
}

\author{
BY EMA HOLEČKOVA \\ Laboratory for the Physiology and Pathophysiology of Metabolism, Czechoslovak \\ Academy of Sciences, Salmovská I, Prague 2, Czechoslovakia \\ AND P. FÁBRY \\ Institute of Human Nutrition, Prague I4, Czechoslovakia \\ (Received 23 Fune 1958-Revised 3 March 1959)
}

When laboratory rats were adapted to intermittent starvation by feeding them without restriction for fixed periods, alternating with gradually increased periods of starvation in which they were given only water, corresponding adaptive changes occurred in their food intake, in the morphology and physiology of the digestive tract and in the biochemical composition of their organs and tissues. The adaptive changes in the food intake and in the stomach are the subject of the present paper.

\section{EXPERIMENTAL}

Female albino rats from a random-bred colony of Wistar origin, of average weight from 100 to $200 \mathrm{~g}$ at the beginning of the experiments, were adapted to intermittent starvation in the manner previously described (Fábry, I955); periods of fasting alternated with single days when the animals had free access to a mixed diet containing $52.8 \%$ of the calories as carbohydrate, $25.5 \%$ as protein and $21.7 \%$ as fat. The periods of fasting for different experimental groups were gradually increased from $\mathrm{I}$ to 3 days during periods of 2 weeks as the minimum and of 6 weeks as the maximum. One group of eighteen rats was thus adapted and fed during 6 weeks, another group of 